\title{
IMPACT OF OIL PRICE VOLATILITY AND MACROECONOMIC VARIABLES ON ECONOMIC GROWTH OF PAKISTAN
}

\section{Muhammad Jawad, Ghulam Shabbir Khan Niazi}

(1) Department of leadership and Management Studies, National Defence University, Islamabad, Pakistan (2) Prof. Ph. D., Department of leadership and Management Studies, National Defence University, Islamabad, Pakistan

Muhammad Jawad

Department of leadership and Management Studies, National Defence University, Islamabad, Pakistan muhammad_jawad85@yahoo.com

Article info Paper category: Original Scientific Paper Received: 23.4.2017. Accepted: 27.4.2017. JEL classification: $\mathrm{E}_{1}, \mathrm{~B}_{22}, \mathrm{O}_{4}$ 


\begin{abstract}
This research analyses the effect of oil price volatility and macroeconomic variables (Trade balance, private sector investment and public sector investment) on economic growth of Pakistan. Linear regression describes the Public sector investment and Trade Balance has significant and oil price volatility and private sector investment has insignificant effect on gross domestic production of Pakistan. Johenson co integration test described the long run relation among the variables. Vector Autoregression, impulse response function and variance decomposition conclude that effect of variables was stable within 10 years and the major part on the variable is due to itself rather than other variables.
\end{abstract}

\title{
Keywords:
}

Oil Price Volatility; Macroeconomic variables; Economic Growth; Pakistan. 


\section{INTRODUCTION}

Crude oil is an important source of energy and used in domestic as well as transport and industrial sector widely. This is the reason it is considered as the crucial and important factor of economical development of the country. Oil demand and supply and price fluctuation also affects stock market throughout the world. Middle East the largest supplier of the crude oil in the world and Asia is considered as the largest consumption of the world.

Oil price changes not only affect economic activities but they also predict the future stability and the effects of price changes on stability. Oil value changes likewise influence the monetary development both decidedly and adversely. The oil price fluctuation in process and high unpredictability not only influence the economy but also different other factors such as gross domestic product (GDP) of the country, import bills and inflation.

Crude oil prices are highly unstable and it has a great impact on economic growth and it arouses many controversies among the policy makers and researchers. Some economic researchers like Akpan (2009), Aliyu (2009) and Olomola (2006) argue that it will promote economic growth while some others like Darby (1982) and Cerralo (2005) argue that it will inhibit economic growth. It was observed in oil exporting countries that increase in oil prices will increase national income of exporting countries.

The oil exporting countries benefited greatly when the oil price increases and they earn huge profits. Governments earn profits and they use those profits for the betterment of their own country. New investment projects are being launched and all the other expenditures are financed through those findings (Hausmann \& Rigobon, 2003).

So that was the case of oil price increase. When oil price decreases, public sector faces disastrous losses because it is difficult for it to reduce the spending immediately. The country will face fiscal imbalances with oil price decrease because country's economy was highly dependent on oil revenues. And due to a decrease in oil revenues, fiscal imbalance occurred. There are large price fluctuations in oil prices consists of sudden increase and sudden decrease. Thus the current pattern is full of price volatilities and it has created large uncertainties in oil market (Sauter and Awerbuch, 2003).

\section{LITERATURE REVIEW}

Most of the research was conducted on developed countries because the developed economies and their economic growth are mainly affected by oil price fluctuations. The observational confirmation demonstrates that oil price shocks have a huge effect on monetary development through some immediate and indirect channels. 
The experimental studies have likewise demonstrated an uneven relationship between oil price shocks and financial subsidence on the planet. Research explains this as an increase in oil price results in the decline in GDP and economic activity and investment is not encouraged due to the decrease in oil price. The sudden increase in oil demand results in increase in oil prices and study shows that it leads to the economic growth of the countries involved in crude oil exports mainly OPEC (Organization of Petroleum Exporting Countries) countries.

If price will increase, it will have adverse affects on output production because overall price increase will also increase the price of input and as a result the earnings will drop. The stock market, if efficient, will experience an immediate decline in stock prices after sudden increase in oil price. Then again securities exchange, if not proficient, will achieve a slacked decrease in the share trading system with an increment in oil cost in oil market.

Numerous financial literary works have exhibited that oil costs unpredictability has negative effect on the total economies. Oil value unpredictability happens because of the unfavorable oil supply stun, i.e. an improve in oil costs moves the total oil supply expanding, results in the increment in value rise and an abatement in efficiency and business (Dornbusch, Fisher and Startz, 2001).

As the developed countries are the biggest consumers of the oil and they are focusing on the reconstruction and that is the reason of their increased demand and also the demand of oil is increasing in the world.

Hamilton (2003) clarified the impact of oil price shocks on financial advancement furthermore clarified the nonlinear oil price shock techniques. He likewise indicates contradiction for the general approach that both deviated and moral presentation of oil price shocks has an effect on money related improvement. They used various macroeconomics variables from 1983 to 2008 and explained the oil price instability.

There is also observed a decline in reserve of oil base which is the reason of oil price volatility. Other factors include Middle East crisis, political unrest in many oil producing and exporting countries, demand supply forces and the quota system of OPEC affect the oil prices greatly and influence the investors to make decisions (Pirog, 2004).

Just like the other raw materials, increase in oil price forced many countries to search for oil and produce their oil and this also caused the downfall of demand worldwide. As many economists promoted energy efficiency and energy conservation to decrease the demand so finally decrease in oil will help a great deal in reducing the oil price.

Due to drop in oil price, demand will once again tend to increase and once again there is a chance of oil price increase in future. The distinctive purpose of perspectives about the oil showcase perceptibly is an indication of unique prospect about the future movement of oil costs (Stevens, 2005). 
Oil is considered a major input for many industries. Many studies conducted on oil market are focused on macroeconomics variables and the effect of these variables on oil prices and stock prices. Many researchers like Rebeca and Sanchez (2004, 2009) Nung et al. (2005), Sandrine and Mignon (2008), Jacobs et al. (2009) and Yazid Dissou (2010) argue that oil price fluctuations and oil price volatility are greatly influenced by macroeconomic variables.

The demand and supply forces determine the oil prices. When there is high demand, price will increase and when there is large supply as compared to demand, the price will decrease. As the countries are becoming modernized and advanced, the demand for oil is increasing and there is large consumption of oil to run domestic as well as industrial sector (Eryigit, 2009).

Kiani (2011) argued there is a continuous increase in the oil prices in Pakistan by OGRA and the reason for this increase is the high demand of energy at all sectors of the economy.

Jamali et al (2011) explained the Pakistan economy and the effects of oil price on economy. They concluded that due to increased oil prices all other variables like inflation rate, interest rate, exchange rate movements, unemployment, low investment, low economic activities, low GDP and low economic growth are adversely affected.

Zamanet et al (2011) described the usage of oil in different sectors of the economy and argued that industrial sector is the largest consumer of oil followed by transport sector and then household sector. All these demand patterns by different sectors ultimately affect the economic growth.

Eksi et al. (2012) again documented that oil is a major input of industrial sector and it is the main and major constitute of economic growth and economic crisis. When there will be increase in oil prices, it will lead to inflation because material and production cost will increase. Thus it will lead to unemployment ultimately.

Salim and Rafiq (2013) used the vector autoregressive (VAR) and Granger causality test and generalized variance decompositions for empirical studies. This study discovers the effect of oil price instability on six noteworthy rising economies of Asia including Indonesia, China, Thailand, India, Philippines and Malaysia.

It is presently very much archived in both exact and hypothetical writing, that oil price shocks apply negative impacts on distinctive macroeconomic pointers through raising creation and operational expenses. This may influence the economy unfavorably on the grounds that they postpone business venture by inducing so as to raise vulnerability or excessive asset reallocation (Salim and Rafiq, 2013).

Muhammad (2013) argued that oil price shocks also has an impact on the economic development while they affect the oil exporting countries and oil importing countries in a different way. On the basis of the results the GDP and economic growth will affect.

Ahmad (2013) examined the situation of Pakistan and also finds out that it depends on the oil in every sector. So when oil price increases it increase the production 
cost, which decrease the investment rate and as a result unemployment decreases.

Siddiqui (2014) explained that investment in oil affect significantly the economic development, economic growth and GDP growth. He also suggested that oil price increase will affect all these variables and also the stock and exchange market.

Katircioglu et al. (2015) examined the association the changes in oil prices and macroeconomic variables (GDP, CPI and unemployment) among 26 OECD economies from 1980 to 2011 . The researchers concluded by econometrics test (Durbin- $\mathrm{H}$ panel co-integration) that changes in oil price has a inverse effect on macroeconomic variables.

After brief review of literature review across different countries, developing and developed economies and from different region of the world, it is observed that the effect of oil price volatility and the macroeconomic variables are not previously viewed, anticipate and define its magnitude in the context of Pakistan.

As Pakistan is a developing economy and has a major role in context of Asia, it is so much important for the policy maker and government of Pakistan to know about the impact of key variables like oil price volatility and macroeconomic variables (Trade Balance, Public sector investment, Private sector investment, Gross Domestic Production) for achieving the improving growth rate.

This research define the magnitude and direction (positive and negative) of oil price volatility and macroeconomic variables (Trade Balance, Public sector investment, Private sector investment, Gross Domestic Production) on economic growth of Pakistan.

\section{DATAAND METHODOLOGY}

\subsection{Theoretical Framework}

The standard growth theories focus on primary inputs such as; capital, labour \& land, while failing to recognize the role of primary energy inputs such as; oil price. However, efforts have been made at evolving some theories which capture the role of oil price volatility on economic growth, thus incorporating the linkage between energy resources; its availability and volatility and economic growth. Just as Moradi, Salehi and Keivanfar (2010), the theories reviewed are primarily reduced-form models, rather than a single theory. The study reviews the following theories: theory of economic growth, linear/symmetric relationship theory of growth, asymmetryin-effects theory of economic growth.

Mainstream theory of economic growth postulates that production is the most important determinant of growth of any economy, and production which is the transformation of matter in some way, requires energy. This theory categorizes capital, labour and land as primary factors of production; these exist at the beginning of the production period and are not directly used up in production (though they can be 
degraded or added to). While energy resources (such as; oil and gas, fuels, coal) are categorized as intermediate inputs, these are created during the production period and are entirely used up during the production process. In determining the marginal product of oil as an energy resource useful in determining economic growth, this theory considers in one part its capacity to do work, cleanliness, amenability to storage, flexibility of use, safety, cost of conversion and so on, it also considers other attributes such as; what form of capital, labour or materials it is used in conjunction with. The theory estimates the ideal price to be paid for crude oil as one that should be proportional to its marginal product.

Linear/Symmetric relationship theory of growth which has as its proponents, Hamilton (1983), Gisser (1985), Goodwin (1985), Hooker (1986) and Laser (1987) postulated that volatility in GNP growth is driven by oil price volatility. They hinged their theory on the happenings in the oil market between 1948 and 1972 and its impact on the economies of oil-exporting and importing countries respectively. Hooker (2002), after rigorous empirical studies demonstrated that between 1948 and 1972 oil price level and its changes exerted influence on GDP growth significantly. Laser (1987), who was a late entrant into the symmetric school of thought, confirms the symmetric relationship between oil price volatility and economic growth. After an empirical study of her own, she submitted that an increase in oil prices necessitates a decrease in GDP, while the effect of an oil price decrease on GDP is ambiguous, because its effects varied in different countries.

Asymmetry-in-effects theory of economic growth posits that the correlation between crude oil price decreases and economic activities in an economy is significantly different and perhaps zero. Mark et al. (1994), members of this school in a study of some African countries, confirmed the asymmetry in effect of oil price volatility on economic growth. Ferderer (1996) another member of this school explained the asymmetric mechanism between the influence of oil price volatility and economic growth by focusing on three possible ways: Counter-inflationary monetary policy, sectoral shocks and uncertainty. He finds a significant relationship between oil price increases and counter-inflationary policy responses. Balke (1996) supports Federer's position/submission. He posited that monetary policy alone cannot sufficiently explain real effects of oil price volatility on real GDP.

My study topic is also related to oil price volatility, exchange rate, fiscal policy effect and economic growth of Pakistan and all above theories supports my research topic.

\subsection{Research Problem}

This research analyses the impact of oil price volatility and macroeconomic variables (Trade balance, private sector investment and public sector investment) on economic growth of Pakistan. Moreover, oil price volatility and macroeconomic 
variable have a significant role in economic growth which is not previously analysis in the context of Pakistan.

\subsection{Data collection procedure}

Secondary data are collected from Institute of Economic Affair (IEA), International Financial Statistics (IFS), World Bank (WB), Ministry of Petroleum \& Natural Resources of Pakistan and Pakistan Bureau of Statistics from 1973 to 2014 for estimation of coefficient. The data contain on yearly basis.

Correlation Coefficient Test

The correlation coefficient is used to measure the linear relationship between two variables. The correlation coefficient values are always lying between negative one $(-1)$ to positive one $(+1)$. A value of +1 of correlation coefficient defined that two variables are perfectly associated in a positive linear sense and -1 define that two variables are perfectly associated in a negative linear sense. Meanwhile, it the value of correlation coefficient is o that indicates there is no linear relationship between the two variables.

Table 1.: Correlation Coefficient Test Results

\begin{tabular}{|l|r|r|r|r|r|}
\hline & $\begin{array}{c}\text { Gross } \\
\text { Domestic } \\
\text { Production }\end{array}$ & $\begin{array}{c}\text { Oil Price } \\
\text { Volatility }\end{array}$ & $\begin{array}{c}\text { Private } \\
\text { Sector } \\
\text { Investment }\end{array}$ & $\begin{array}{c}\text { Public } \\
\text { Sector } \\
\text { Investment }\end{array}$ & $\begin{array}{c}\text { Trade } \\
\text { Balance }\end{array}$ \\
\hline $\begin{array}{l}\text { Gross Domestic } \\
\text { Production } \\
\text { Oil Price Volatility }\end{array}$ & -0.1774 & 1 & & & \\
$\begin{array}{l}\text { Private Sector } \\
\text { Investment }\end{array}$ & 0.9183 & -0.2010 & 1 & & \\
$\begin{array}{l}\text { Public Sector } \\
\text { Investment } \\
\text { Trade Balance }\end{array}$ & 0.8067 & -0.2194 & 0.9206 & & \\
\hline
\end{tabular}

Source: Autors`

Table 1 describes the correlation coefficient among the five variables Oil Price Volatility, Trade Balance, Private Sector Investment, Public Sector Investment and Gross Domestic Production (GDP) of Pakistan.

It is described in the above table that Gross Domestic Production has strong positive relation with Private Sector Investment (correlation coefficient value of 0.9183 ), Public Sector Investment (correlation coefficient value of 0.8067 ) and Trade Balance (correlation coefficient value of o.6299). It is viewed that Gross Domestic Production has a negative weak relation exist with Oil Price Volatility (correlation coefficient value of -0.1774). It is defined in the above table that Oil Price Volatility has moderate negative relation with Private Sector Investment (correlation 
coefficient value of -0.2010) and Public Sector Investment (correlation coefficient value of - 0.2194 ). Meanwhile, it is viewed that Oil Price Volatility has a weak negative relationship exist with Trade Balance (correlation coefficient value of -0.1901).

It is observed in the above table that Private Sector Investment has strong positive relation with Public Sector Investment (correlation coefficient value of 0.9206). Meanwhile, it is viewed that Private Sector Investment has moderate positive relationship with Trade Balance (correlation coefficient value of 0.5445 ). It is described in the above table that Public Sector Investment has moderate positive relationship with Trade Balance (correlation coefficient value of o.3882).

\subsection{Linear Regression}

Linear regression model with OLS techniques is used for analysis.

Gross Domestic Production $=\beta 0+\beta_{1} \mathrm{OPV}+\beta_{2} \mathrm{PRS}+\beta 3 \mathrm{PS}+\beta_{4} \mathrm{~TB}+\varepsilon$

The linear Regression analysis is run on the dependent variable Gross Domestic Production and the independent variables Trade Balance, Public sector investment, Private sector investment and the Oil price volatility (defined through standard deviation) to find out the impact of oil price volatility and other macro economic variables on the economic growth of Pakistan. The results are described by the following equation

$$
\text { GDP }=9.999+0.017 \text { OPV }-0.123 \text { PRS }+0.944 \text { PS }-0.167 \text { TB }
$$

Table 2.: Linear Regression Model Result

\begin{tabular}{|l|r|r|r|r|}
\hline \multicolumn{1}{|c|}{ Predictor } & Coefficient & $\begin{array}{c}\text { Standard } \\
\text { Deviation }\end{array}$ & \multicolumn{1}{c|}{ T } & \multicolumn{1}{c|}{ P } \\
\hline Constant & 9.999 & 0.968 & 10.325 & 0.000 \\
OPV & 0.017 & 0.250 & 0.283 & 0.779 \\
PRS & -0.123 & 0.136 & $-0.75^{1}$ & $0.45^{8}$ \\
PS & 0.944 & 0.079 & 5.296 & 0.000 \\
TB & -0.167 & 0.064 & -2.199 & 0.034 \\
\hline
\end{tabular}

$R-S q=93.3 \% R-S q(a d j)=87.0 \%$

Source: Autors`

The equation illustrates the constant value of 9.999 units which mean without any change in other independent variables, the constant independently change the GDP by 9.999 units. After that the oil price volatility have the coefficient value of 0.017 which is positively impacted and also depict that one positive change in oil price volatility have positively change GDP of Pakistan by 0.017 unit. The regression equation also denominate that private sector investment (which is represented through PRS) has also a negative impact on GDP of Pakistan and one unit change in private sector investment would change GDP of Pakistan by 0.123 units. Conse- 
quently, the analysis about public sector investment, it has positive impact on GDP of Pakistan and one unit change in public sector investment may change the GDP of Pakistan by 0.944 units. In contrast with other independent variable Trade balance have a negative impact on GDP of Pakistan and if one unit change in Trade Balance would change GDP of Pakistan by negatively 0.167 units. The regression table describes that oil price volatility value and private sector investment value is not even significant at $10 \%$ level of significance but at the same time public sector investment value is significance at $1 \%$ level of significant. The table illustrates that trade balance value is significant at $5 \%$ level of significance.

The R square value in the Linear Regression equation described that the independent variables Trade Balance, private sector investment, public sector investment and oil price volatility describe the dependent variable Gross Domestic Production of Pakistan by almost $87 \%$. The remaining portion of GDP of Pakistan is impact through other macro-economic variables which is only $13 \%$.

\section{$3 \cdot 5$. Johenson co integration test}

The Johenson co integration test is used to find out the short run and long run relation among the variables. The following results described by using the Johenson co integration test on oil price volatility, trade balance, private sector investment, public sector investment and gross domestic production:-

Table 3.: Johenson co integration test Result

\begin{tabular}{|l|r|r|r|r|}
\hline $\begin{array}{c}\text { Hypothesized } \\
\text { No } \\
\text { of CE(s) }\end{array}$ & Eigen value & Trace Statistic & $\begin{array}{c}\text { 0.05 Critical } \\
\text { value }\end{array}$ & Probability \\
\hline None* $^{*}$ & $0.65297^{8}$ & 128.5686 & 69.81889 & 0.0000 \\
At most $\mathbf{1}^{*}$ & 0.594215 & 87.29219 & 47.85613 & 0.0000 \\
At most $2^{*}$ & 0.471945 & 52.11686 & 29.79707 & 0.0000 \\
At most $3^{*}$ & 0.391162 & 27.21321 & 15.49471 & 0.0006 \\
At most $4^{*}$ & 0.182554 & 7.861257 & 3.84 .1466 & $0.005^{1}$ \\
\hline
\end{tabular}

Source: Autors`

Johenson co integration test define that there is 5 co integration equations at level 0.05 . So it is concluded that oil price volatility, trade balance, private sector investment, public sector investment and gross domestic production have a long run relationship. 


\section{VAR MODEL}

We estimated our results through stationary data although according to (Phillip Fanchon and Jeanne Wendel, 2006) VAR models can be predictable with raw data in the levels if the non-stationary data is also co-integrated because current theoretical work demonstrate that estimation with such data will yield consistent parameter estimates but at the same time all economist and econometrics professional is agreed that for VAR model we used stationary data for effective and accurate parameters.

Table4.: VAR Result Table

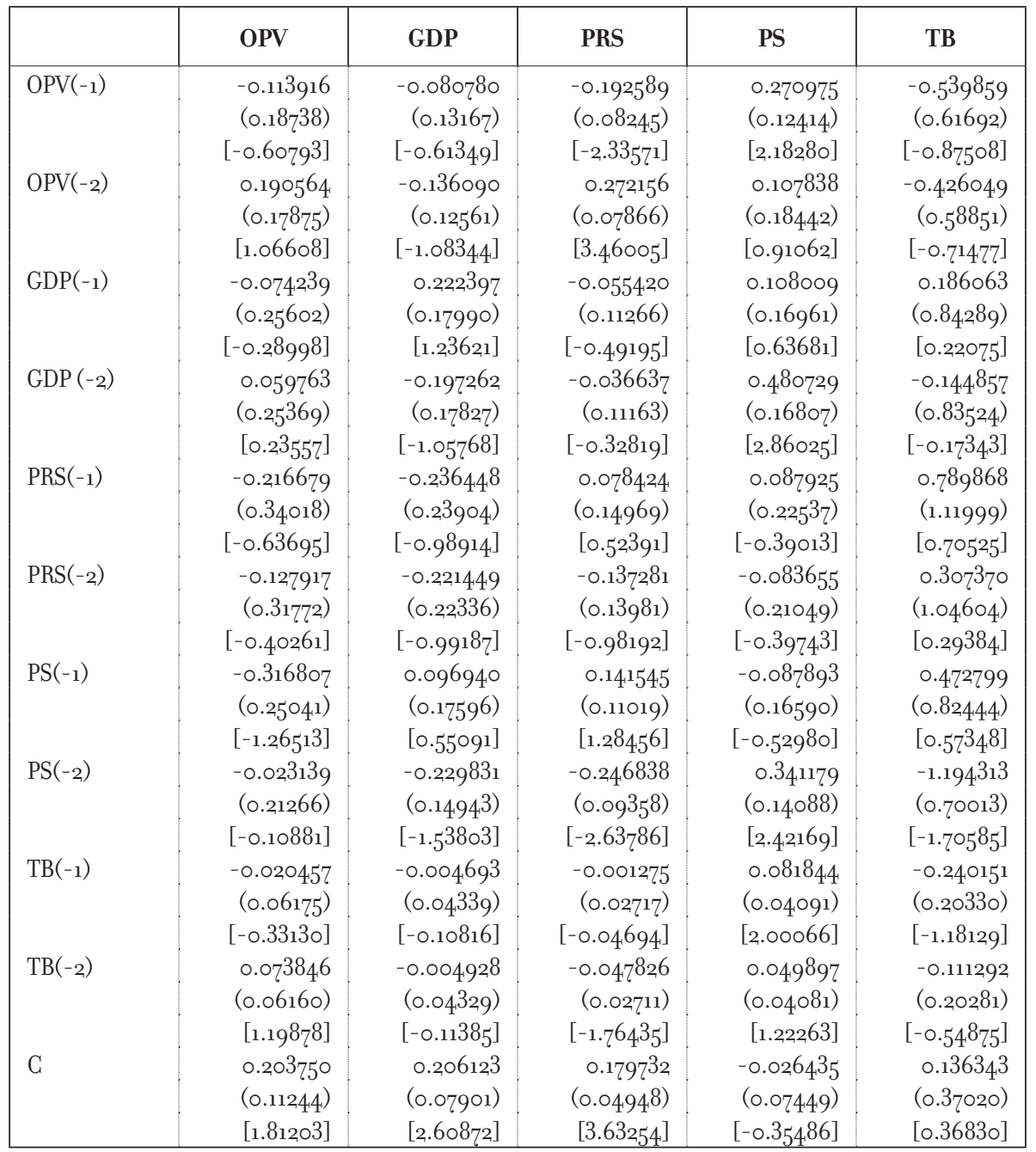

Source: Autors` 
The analysis described that Oil price volatility Auto Regress by itself, gross domestic production, private sector investment, public sector investment, trade balance, its coefficient value is $-0.113916,--0.080780,-0.1925^{89}, 0.270975$ and -0.539859 respectively and its $t$ value is $-0.60793,-0.61349,-2.33571,2.18280$ and -0.87508 accordingly at lag (1). Meanwhile, its coefficient value is 0.190564 , $-0.136090,0.272156,0.107838$ and -0.426049 respectively and its t-value is $1.06608,-1.08344,3.4,6005,0.91062$ and -0.71477 accordingly at lag (2)

Consequently, GDP of Pakistan Auto Regress by oil price volatility, itself, private sector investment, public sector investment and trade balance, its coefficient value is $-0.074239,0.222397,-0.0554,20,0.108009$ and 0.186063 respectively and its t value is $-0.28998,1.23621,-0.49195,0.63681$ and 0.22075 accordingly at lag (1). Meanwhile, its coefficient value is $0.059763,-0.197262,-0.036637,0.4,80729$ and -0.144 .857 respectively and its t value is $0.23557,-1.05768,-0.32819,2.86025$ and - $0.1734,3$ accordingly at lag (2).

Meanwhile, private sector investment Auto Regress by oil price volatility, GDP of Pakistan, itself, public sector investment and trade balance, its coefficient value is $-0.216679,-0.236448,0.078424,0.087925$ and 0.789868 respectively and its tvalue is $-0.63695,-0.98914,0.52391,-0.39013$ and 0.70525 accordingly at lag (1). Meanwhile, its coefficient value is $-0.127917,-0.221449,-0.137281,-0.083655$ and 0.307370 respectively and its t value is $-0.40261,-0.99187,-0.98192,-0.3974,3$ and 0.29384 accordingly at lag (2).

In the same time, public sector investment Auto Regress by oil price volatility, GDP of Pakistan, private sector investment, itself and trade balance, its coefficient value is $-0.316807,0.096940,0.141545,-0.087893$ and 0.472799 respectively and its t value is $-1.26513,0.55091,1.28456,-0.52980$ and 0.57348 accordingly at lag (1). Meanwhile, its coefficient value is $-0.023139,-0.229831,-0.246838,0.34,1179$ and -1.194313 respectively and its $t$ value is $-0.10881,-1.538 \circ 3,-2.63786,2.42169$ and -1.70585 accordingly at lag (2).

Meantime, trade balance Auto Regress by oil price volatility, GDP of Pakistan, private sector investment, public sector investment and itself, its coefficient value is $-0.020457,-0.004693,-0.001275,0.081844$ and $-0.24,015^{1}$ respectively and its $\mathrm{t}$ value is $-0.33130,-0.10816,-0.04694,2.00066$ and -1.18129 accordingly at lag (1). Meanwhile, its coefficient value is $0.073846,-0.004928,-0.047^{82} 6,0.049897$ and -0.111292 respectively and its t value is $1.19878,-0.11385,-1.764,35,1.22263$ and -0.54875 accordingly at lag (2).

In the VAR Model the constant coefficient values of oil price volatility, GDP of Pakistan, private sector investment, public sector investment, trade balance are $0.203750,0.206123,0.1797^{32},-0.0264,35$ and $0.13634,3$ respectively and its t value is $1.81203,2.60872,3.63254,-0.354,86$ and 0.36830 accordingly at lag (1). 


\section{IMPULSE RESPONSE FUNCTION}

Impulse Response function is used to analyze the shocks and innovation. Impulse response function (IRF) refers to the effect of any external change.

Figure 1.: Impulse response function of OPV

Response to Cholesky One S.D. Innovations \pm 2 S.E.

Response of OPV to OPV

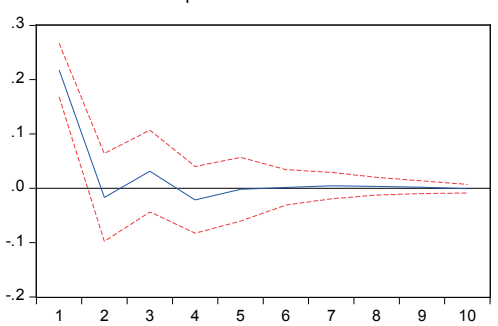

Response of OPV to DPRS

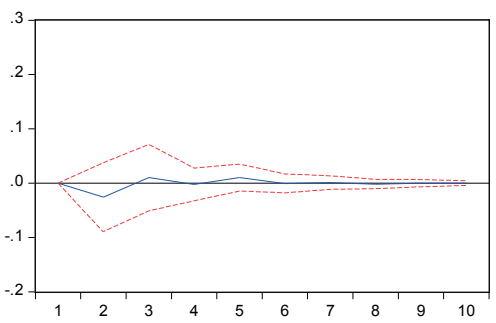

Response of OPV to DTB

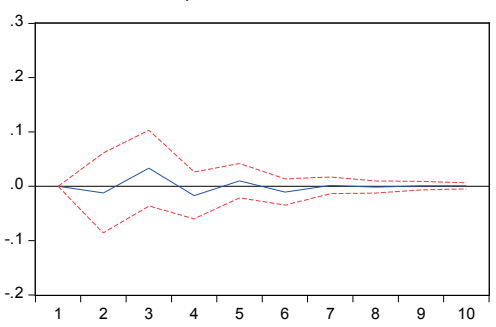

Response of OPV to DGDP

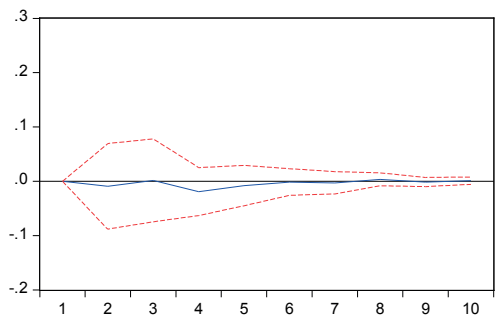

Response of OPV to DPS

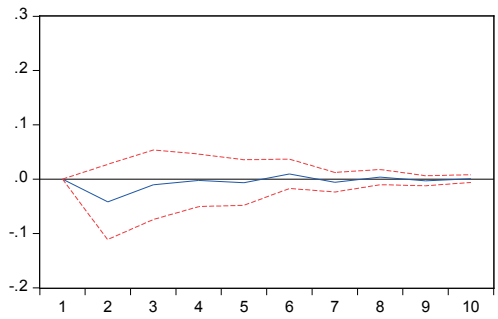

Source: Autors

After VAR Model, Impulse Response function is used to analyze the shocks and innovation. It is observed through Impulse Response Function that oil price volatility shock start its effect on oil price volatility and sharply decreases and goes in negative side. After that it was slightly increase and decrease and found in negative and positive side of the zero level. Oil price volatility shock was stable after 7 year and its stabilizing trend continued till the further instability policy effect again. Mean while, 
oil price volatility shock effect the GDP and it dramatically start from the negative side of the zero line go downward and then upward but remain in the negative side and finished after 5 year and that stabilize condition continued at last. Oil price volatility shock also affecting the private sector investment and it's also start from negative side from the zero line but move upward in positive side till 5 year. The shock was stabilizing after 5 year and this stabilizing effect continued.

Furthermore, oil price volatility shock also effects the public sector investment and its start below from zero line. Afterward the shock slowly increasing and go on positive side after 5 year. The oil price volatility shock stabilizes after 8 year and stabilizing effect go on till end. Consequently, oil price volatility shock also effect trade balance and as before it's also start from negative side but afterward dramatic increasing and decreasing trend start. The shock was stabilized after 7 year and after that no further destabilization is found in it.

Figure 2.: Impulse response function of GDP

Response to Cholesky One S.D. Innovations \pm 2 S.E.
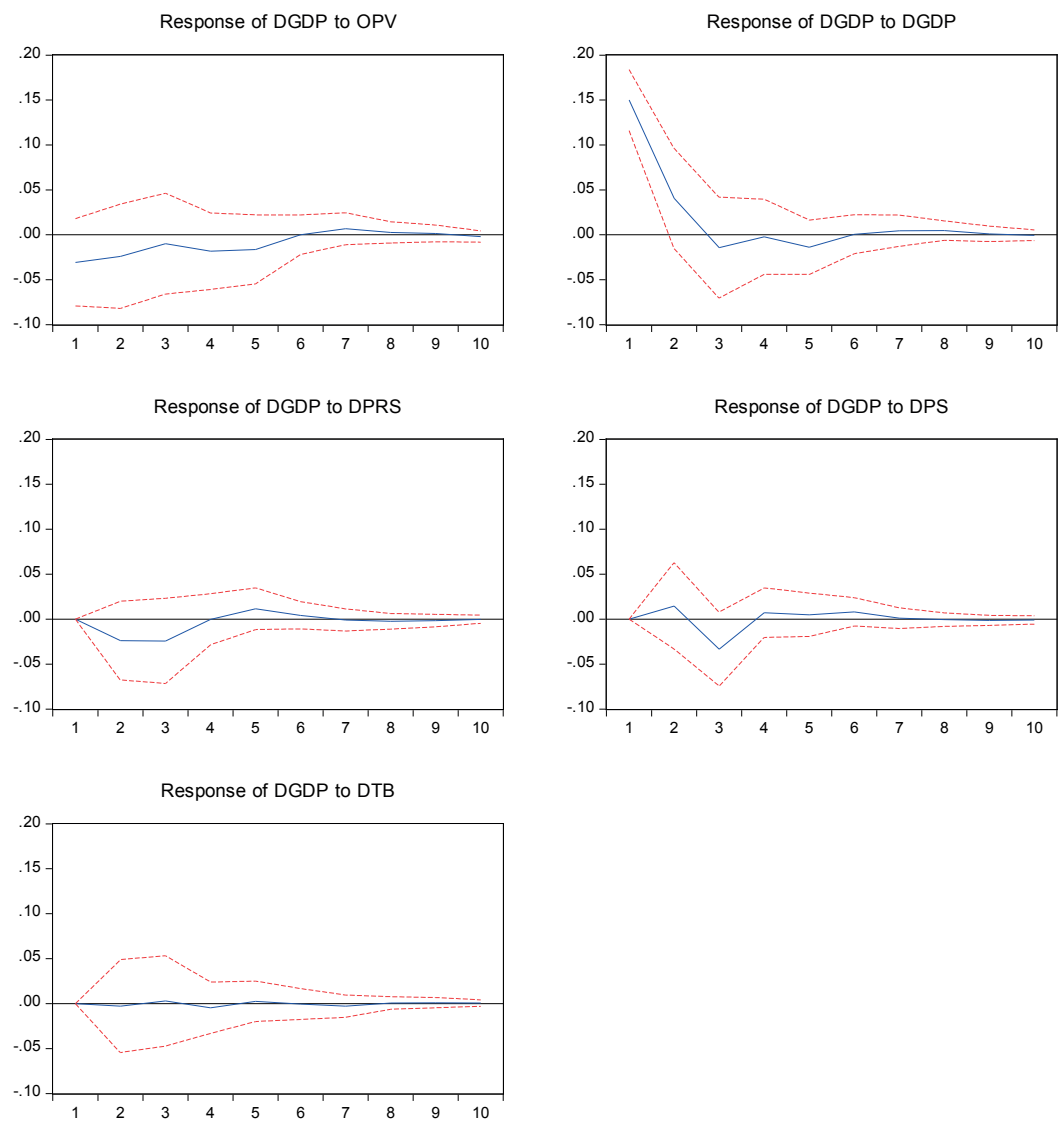

Source: Autors` 
The second impulse response function related to gross domestic production of Pakistan. It is observed through impulse response function gross domestic production shock effect the oil price volatility and its start from negative side of the zero line and slowly increasing till 6 year and afterward go on the positive side. The shock was stabilized after 8 year and no further instability was found.

Moreover, gross domestic production shock also effect gross domestic production. Its start from positive side and steeply decreased and go in negative side with respect to zero line and that instability was found till 9 year. Afterward stable response was found in gross domestic production.

In addition, gross domestic production shock effect private sector investment and its start from the negative side and after 3 year the shock response goes in positive side with respect to zero line. The shock stabilized after 9 year and further goes on.

Accordingly, gross domestic production shock also effect public sector investment. The shock start from positive side with the reference of zero line but later on it's steeply goes to the negative side. Then the shock slowly moves upward and goes in positive size and stabilized after 7 year and further no instable effect was found.

At last, gross domestic production shock also effect the trade balance but the shock effect is so much minor but the instability goes its effect on negative and positive side continuously. The shock stabilized after 8 year. 
Figure 3.: Impulse response function of PRS
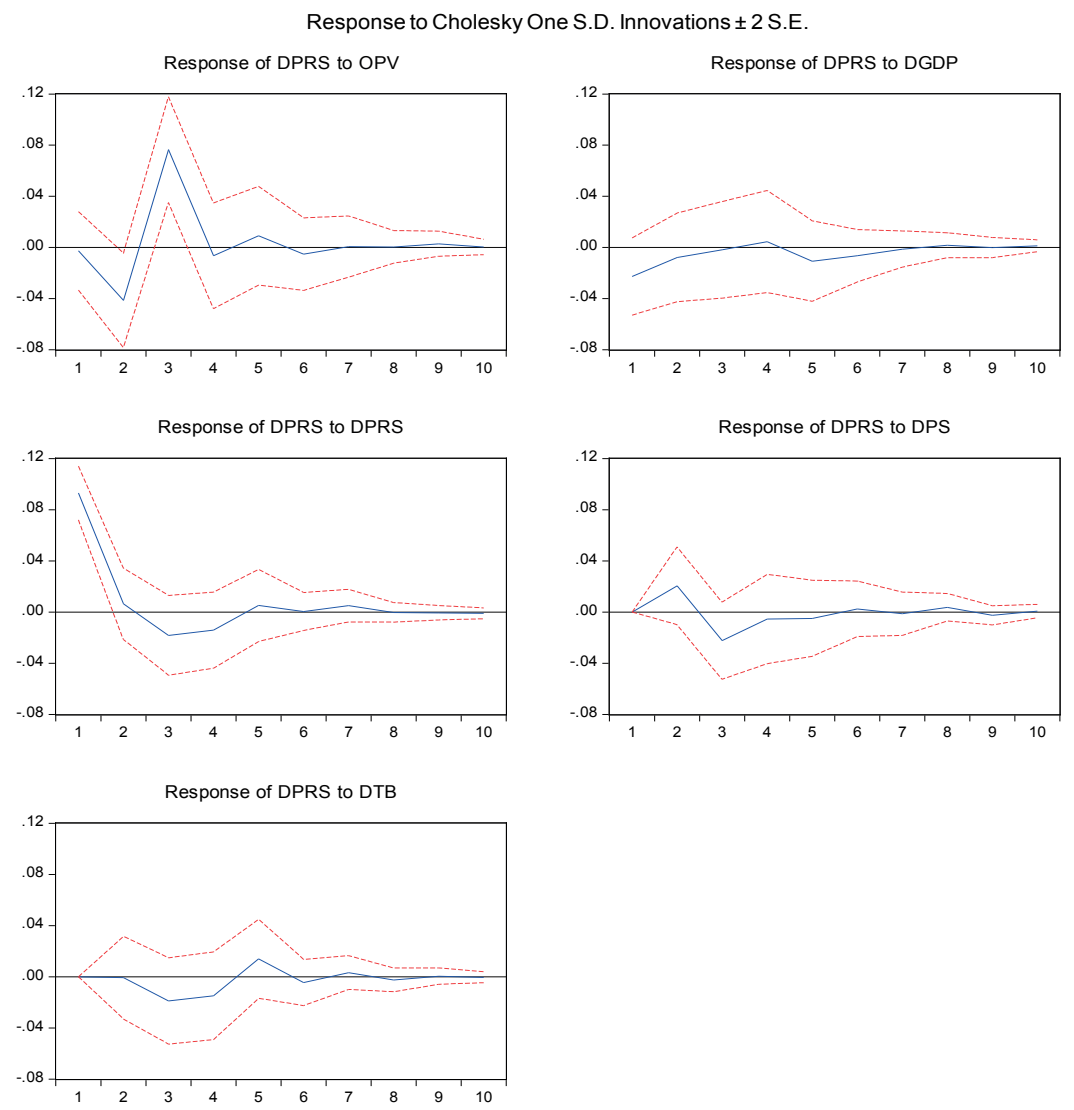

Source: Autors`

The third impulse response function is related to private sector investment on different macroeconomic variables. It is viewed that private sector investment shock effect the oil price volatility dramatically. Its start from negative side with respect to zero line but afterward it goes on positive side sharply. Then the shock effect goes down in negative side afterward low instability was found till 9 year and stability was found.

Furthermore, private sector investment shocks effect on gross domestic production and its start from the negative side and increasing slowly toward the positive side. After a low volume in positive side with respect to zero line, the shock again goes in negative side and stabilized after 8 year and further no instability was found.

Moreover, private sector investment shock also effect private sector investment. Its start from positive side and steeply decreased and go in negative side with respect to zero line and that instability was found till 8 year. Afterward stable response was found in private sector investment. 
In addition, private sector investment shock also effect public sector investment and its start from positive side and goes upward. Afterward the shock decreases and goes in negative side with respect to zero line. Then slow positive trend was found and the shock was stabilized after 9 year till end. Consequently, private sector investment shock also effect trade balance. The shock start from the negative side and increasing trend in negative side was found. Afterward the decreasing trend was found in the shock and goes in positive side with reference to zero line. The instability was found till 8 year and further no volatility was found.

Figure 4.: Impulse response function of PS

Response to Cholesky One S.D. Innovations \pm 2 S.E.
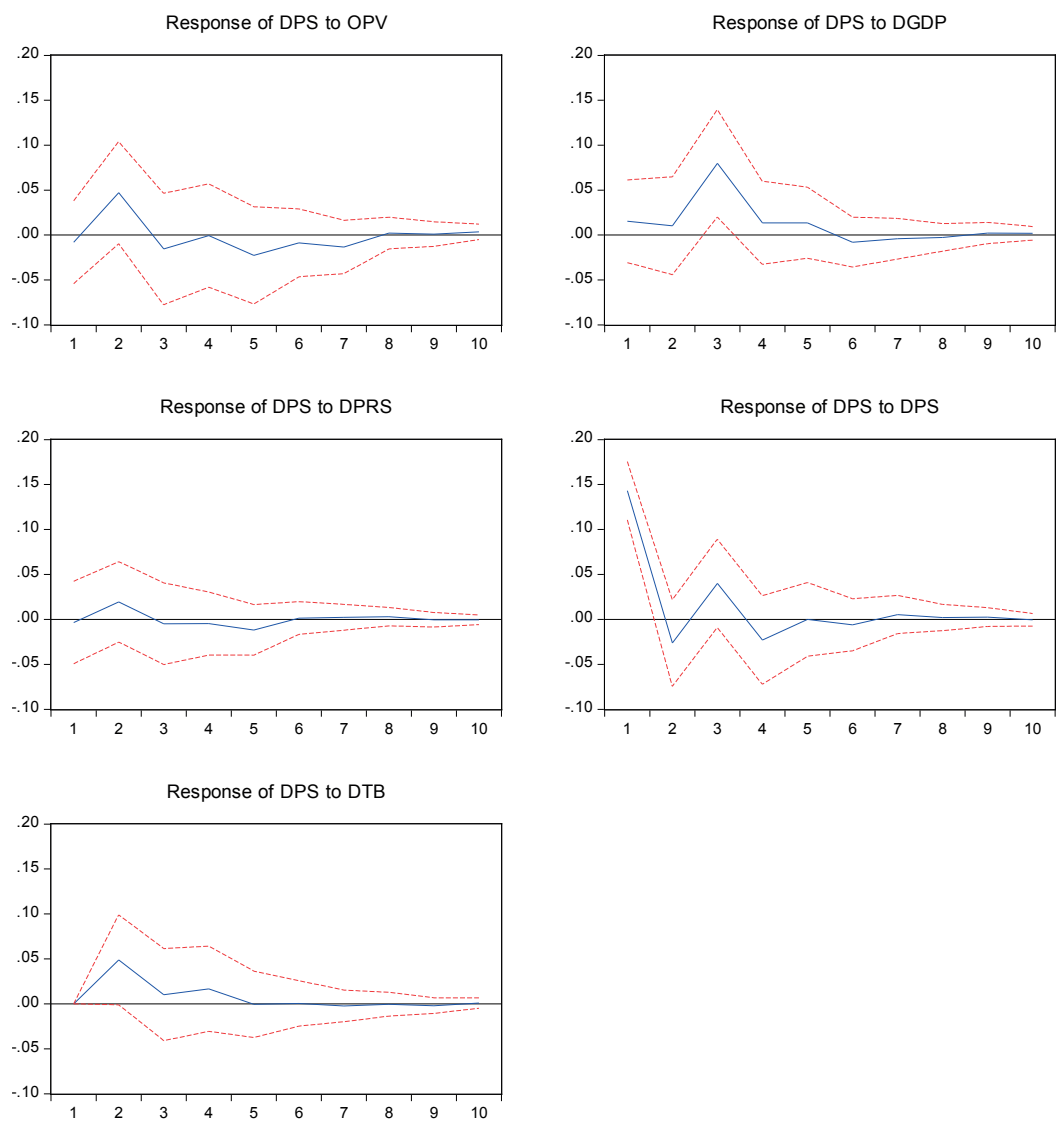

Source: Autors

The forth impulse response function is associated to public sector investment. It is observed via impulse response function that public sector investment shock effect the oil price volatility. Its start from the negative side but instantly goes on positive side with respect to zero line. Afterward dramatically change was found till 8 year 
and the public sector investment stabilized and no further instability was observed. Consequently, Public sector investment shock effect the gross domestic production of Pakistan. At start the shock was found in positive side but after that a sharp increase and decrease was observed. The shock was stabilized after 8 year and further stable response was found.

Meanwhile, Public sector investment shock also effect the private sector investment and it is viewed that the shock was start from the negative side with respect to zero line and increasing and decreasing trend was found. The shock was stabled after 6 year and goes on.

Furthermore, public sector investment shock also effect public sector investment. Its start from positive side and steeply decreased and go in negative side with respect to zero line and that instability was found till 7 year. Afterward stable response was found in public sector investment. Additionally, public sector investment shock effect trade balance and it is viewed that the shock was start from the positive side with reference to zero line and increased. Afterward the shock was decreasing and found stable after 5 year and further no instability was observed.

Figure 5.: Impulse response function of TB
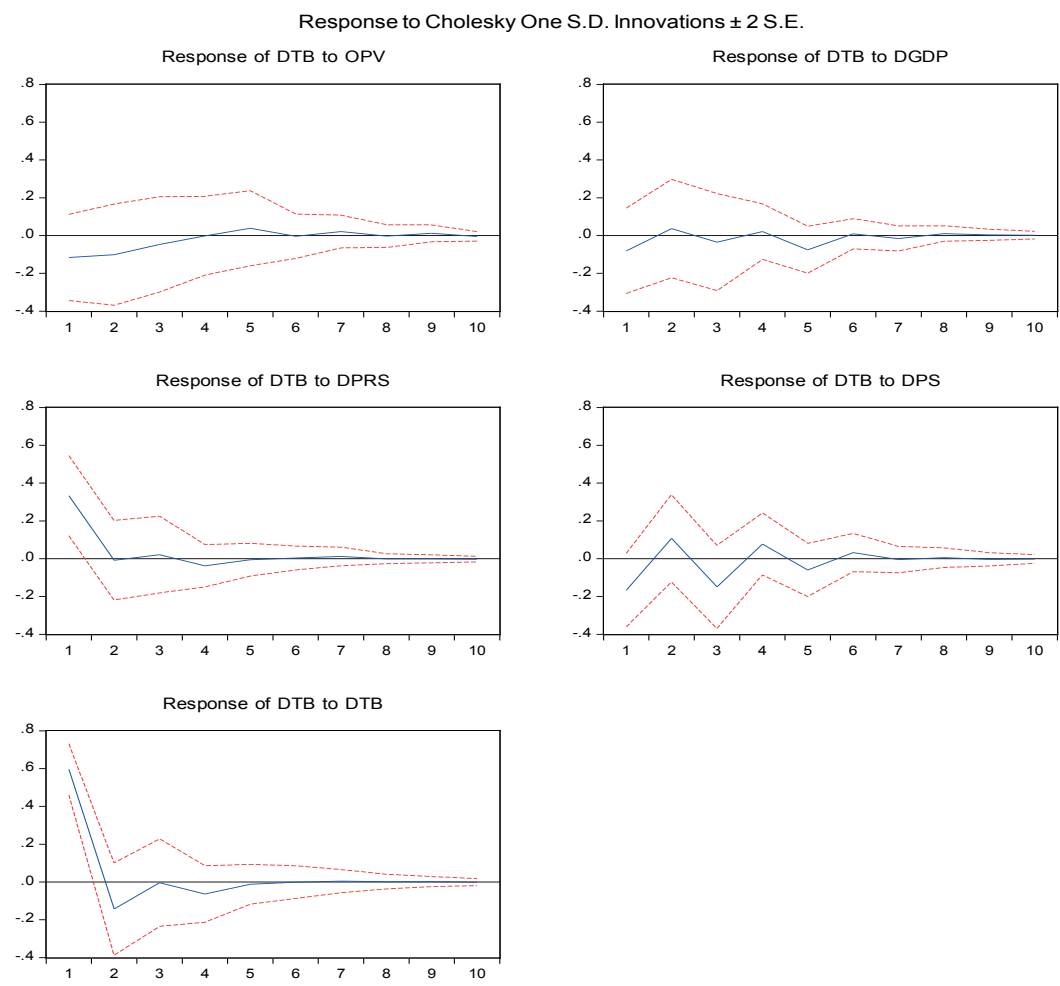

Source: Autors` 
The fifth and the last impulse response function is related to trade balance. It is observed with respect to impulse response function that the trade balance shock effect the oil price volatility. The shock initiate from the negative side with reference to zero line and increasing slowly. Afterward the shock was found in positive side and stabled after 9 year. No further instability was found with respect to the effect of trade balance shock.

Meanwhile, trade balance shock also effect gross domestic production of Pakistan. The shock start from the negative side and continuous increasing and decreasing trend was found. The shock was stabled after 8 year and further goes on.

Consequently, trade balance shock effects the private sector investment. Its start from the positive side with respect to zero line but steeply decreasing. Afterward, the shock was observed in positive and negative side in different time spam and stabilized after 7 year. The stabilized effect was observed till end.

Furthermore, trade balance shock also effects the public sector investment. The shock initiate from the negative side but sharp movement which make the shock trend in positive side and negative side in different time spam was observed. The stability effect of the shock was observed after 7 year and remains stabled afterward.

At last, trade balance shock also effect trade balance and it is viewed that shock start from positive side with respect to zero line. Afterward, the shock decreased steeply and goes on the negative side and remains there till end. The increasing and decreasing trend was observed there but the shock never cross the zero line and lye in the positive side. The shock was stabilized after 5 year and that effect remain constant till end.

\section{VARIANCE DECOMPOSITION}

Variance decomposition is used to help out in the explanation of a vector autoregression (VAR) model after its implementation. The variance decomposition defined the value attribute to each variable to the other variables in autoregression.

The under mentioned table 8 described the variance decomposition of oil price volatility (OPV) by statistical analysis. It is viewed in the table that at first year all variation on OPV is due to itself $100 \%$ and other macroeconomic variables trade balance (TB), private sector investment (PRS), public sector investment (PS), and gross domestic production (GDP) have no contribution on OPV variation. Consequently, it is observed that increasing variation contribution by public sector investment is viewed on OPV by $4.02 \%$ and OPV itself variation is decreased by $94.7 \%$ and TB, PRS and GDP jointly contributed $1.2 \%$ of variation. After 6 year the variation is viewed as constant and stabilized trend up to 10 year and the variation on OPV due to itself, TB, PRS, PS and GDP is 90.33\%, 3.54\%, 1.13\%, 4..66\% and $0.94 \%$ respectively. 
Table 5.: Variance Decomposition of GDP

\begin{tabular}{|l|r|r|r|r|r|r|}
\hline \multicolumn{7}{|c|}{ Variance Decomposition of OPV } \\
\hline Period & S.E. & OPV & TB & PRS & PS & GDP \\
1 & 0.217792 & 100.00 & 0.000000 & 0.000000 & 0.000000 & 0.000000 \\
2 & 0.2244 .81 & $94.7057^{3}$ & 0.263740 & 0.778046 & 4.022915 & 0.229571 \\
3 & 0.229563 & 92.44 .012 & 2.585186 & 0.881500 & 3.847384 & $0.245^{814}$ \\
4 & 0.232018 & 91.35141 & 2.84 .0396 & 1.032605 & 3.909416 & 0.866174 \\
5 & 0.232696 & 90.82761 & 3.275761 & 1.069609 & 3.916949 & 0.910071 \\
6 & 0.233150 & 90.4774 .8 & 3.500935 & 1.132319 & 3.972974 & 0.916290 \\
7 & 0.233295 & 90.4 .0677 & 3.507708 & 1.320319 & 4.020954 & 0.923644 \\
8 & 0.233387 & 90.35715 & 3.536413 & 1.131926 & 4.0399932 & 0.934582 \\
9 & 0.233425 & 90.33411 & 3.540039 & 1.132371 & 4.055994 & 0.937483 \\
10 & 0.233431 & 90.33089 & 3.539863 & 1.132701 & 4.05794 .8 & 0.938601 \\
\hline
\end{tabular}

Source: Autors'

The following Table 6. explained the variance decomposition of trade balance (TB). It is observed in the table that at first year maximum variation on trade balance is due to itself $97.39 \%$ but meanwhile trade balance also has a little variation due to oil price volatility (OPV) by 2.61\% and other macroeconomic variables private sector investment (PRS), public sector investment (PS), and gross domestic production (GDP) have no contribution on trade balances (TB) variation. There is no dramatic contribution in variation upon trade balance is viewed due to other macroeconomic variables. After 10 year the variation is viewed on trade balances (TB) due to OPV, itself, PRS, PS and GDP is 4. $59 \%, 87.85 \%, 0.77 \%, 5.81 \%$ and $0.97 \%$ correspondingly.

Table 6.: Variance Decomposition of TB

\begin{tabular}{|l|r|r|r|r|r|r|}
\hline \multicolumn{7}{|c|}{ Variance Decomposition of TB } \\
\hline Period & S.E. & OPV & TB & PRS & PS & GDP \\
1 & 0.717039 & $2.60997^{8}$ & 97.39002 & 0.000000 & 0.000000 & 0.000000 \\
2 & 0.746938 & 4.247174 & 93.99863 & 0.787689 & 0.836267 & 0.130245 \\
3 & 0.764266 & 4.433250 & 90.15105 & 0.762580 & 4.492214 & 0.160910 \\
4 & 0.772044 & $4.34485^{3}$ & 89.76848 & 0.749265 & 4.974979 & 0.162427 \\
5 & 0.779142 & 4.512049 & $88.155^{6} 7$ & 0.747728 & 5.659253 & 0.925301 \\
6 & 0.779863 & 4.506595 & 88.00240 & 0.750868 & 5.809707 & 0.930428 \\
7 & 0.780414 & 4.570671 & 87.90225 & 0.768242 & 5.805514 & 0.953326 \\
8 & 0.780509 & 4.571366 & 87.88123 & 0.769521 & 5.810820 & 0.967065 \\
9 & 0.780613 & 4.592273 & 87.85803 & 0.770416 & 5.810491 & 0.968789 \\
10 & 0.780639 & 4.595855 & 87.85276 & 0.771710 & 5.810787 & 0.968886 \\
\hline
\end{tabular}

Source: Autors 
The subsequent Table 5. clarified the variance decomposition of private sector investment (PRS). It is viewed, first year main variation on PRS is due to itself $76.48 \%$ but meanwhile PRS also have a moderate variation due to trade balance (TB) by $23.44 \%$. Furthermore, PRS has a minute vibration due to oil price volatility (OPV) by $0.08 \%$ and other macroeconomic variables public sector investment (PS), and gross domestic production (GDP) have no contribution on PRS variation. There is an impressive contribution in variation upon PRS is viewed due to OPV, TB and PS in second year by $15.09 \%, 18.87 \%$ and $3.09 \%$ respectively. The variation is viewed on PRS after 10 year due to OPV, TB, itself, PS and GDP is $39.42 \%, 16.29 \%, 37.14 \%$, $6.09 \%$ and $1.05 \%$ in the same way.

Table 7.: Variance Decomposition of PRS

\begin{tabular}{|c|c|c|c|c|c|c|}
\hline \multicolumn{7}{|c|}{ Variance Decomposition of PRS } \\
\hline Period & S.E. & OPV & TB & PRS & PS & GDP \\
\hline 1 & 0.095835 & 0.078304 & 23.44557 & $7^{6.47613}$ & 0.000000 & 0.000000 \\
\hline 2 & 0.106882 & 15.09474 & 18.87076 & $62.3735^{2}$ & 3.096647 & 0.564335 \\
\hline 3 & $0.135^{894}$ & 40.98689 & 13.654 .87 & 39.04133 & 5.902567 & $0.414,347$ \\
\hline 4 & $0.1377^{8} 5$ & 40.09384 & 15.08047 & 38.21735 & 6.185459 & 0.422880 \\
\hline 5 & 0.139398 & $39 \cdot 5957^{8}$ & 16.15763 & $37.34,027$ & 6.062886 & $0.84,34,36$ \\
\hline 6 & 0.139749 & $39 \cdot 54.084$ & 16.13904 & $37.24,063$ & 6.033680 & $1.045^{815}$ \\
\hline 7 & 0.139889 & $39 \cdot 464,20$ & 16.26272 & 37.20660 & 6.022715 & $1.04,377^{8}$ \\
\hline 8 & 0.139970 & $39 \cdot 41882$ & 16.30079 & 37.16894 & 6.061134 & $1.05 \circ 316$ \\
\hline 9 & $0.14,0025$ & $39 \cdot 4 \cdot 2791$ & $16.2905^{8}$ & $37.145^{3} 4$ & 6.086645 & $1.0495^{3 \circ}$ \\
\hline 10 & $0.14,0037$ & $39 \cdot 4214.8$ & 16.29545 & $37.14,224$ & 6.087288 & $1.05^{3} 5^{3} 7$ \\
\hline
\end{tabular}

Source: Autors

The under state Table 7 . explained the variance decomposition of public sector investment (PS). It is observed that at first year major variation on PS is due to itself $92.35 \%$ but meanwhile PS also has a considerable variation due to trade balance (TB) by 6.59\%. Oil price volatility (OPV) and private sector investment (PRS) have a minor contribution in variation by $0.3 \circ \%$ and $0.75 \%$ respectively and gross domestic production (GDP) have no contribution on PS variation. There is an impressive contribution in variation upon PS is viewed due to trade balance (TB) in second year by $16.63 \%$. The variation observed later than 10 year on PS due to OPV, TB, PRS, itself and GDP is $8.91 \%, 13.15 \%, 3.27 \%, 59.20 \%$ and $15.4,6 \%$ respectively which mean variation in public investment (PS) is mainly contributed by trade balance and gross domestic production. 
Table 8.: Variance Decomposition of PS

\begin{tabular}{|c|c|c|c|c|c|c|}
\hline \multicolumn{7}{|c|}{ Variance Decomposition of PS } \\
\hline Period & S.E. & OPV & $\mathrm{TB}$ & PRS & PS & GDP \\
\hline 1 & 0.144287 & 0.307945 & $6.5^{8} 7^{663}$ & 0.752030 & 92.35236 & 0.000000 \\
\hline 2 & $0.163 \circ 70$ & $8.6045^{30}$ & $16.6333 \circ$ & 1.116644 & $72 \cdot 72469$ & 0.920836 \\
\hline 3 & 0.186907 & $7 \cdot 24,3687$ & 13.08868 & 2.032893 & 62.19740 & 15.43734 \\
\hline 4 & 0.189590 & 7.041135 & 13.40942 & 2.837995 & $61.184,33$ & $15 \cdot 52713$ \\
\hline 5 & 0.191787 & 8.282709 & 13.2604 .0 & 3.201569 & $59 \cdot 79256$ & $15 \cdot 46276$ \\
\hline 6 & 0.192257 & $8.45^{3396}$ & 13.22707 & $3.1955^{\circ} 3$ & 59.61067 & $15 \cdot 51337$ \\
\hline 7 & 0.192871 & 8.880721 & 13.15060 & $3.23247^{1}$ & 59.2794 .1 & $15 \cdot 45680$ \\
\hline 8 & 0.192939 & $8.8875^{88}$ & 13.14 .305 & 3.266760 & $59 \cdot 244.62$ & $15.4579^{8}$ \\
\hline 9 & 0.192979 & $8 . .886068$ & $13.157^{6} 7$ & 3.265914 & 59.23107 & 15.45928 \\
\hline 10 & 0.193021 & 8.913884 & 13.15233 & 3.269166 & $59.205^{11}$ & $15.4595^{1}$ \\
\hline
\end{tabular}

Source: Autors`

The next Table 8. gives details about the variance decomposition of gross domestic production (GDP). It is viewed that at first year most important variation on GDP is due to itself $89.62 \%$ but meanwhile private sector investment (PRS) also have a minor variation by $4.18 \%$. Oil price volatility (OPV) and trade balance (TB), public sector investment (PS) have also contributed in GDP variation by $4.02 \%, 1.25 \% \%$ and $0.93 \%$ respectively. After 10 year the variation on GDP due to OPV, TB, PRS, PS and itself is $7.67 \%, 2.94 \%, 8.01 \%, 5 \cdot 74 \%$ and $75.64 \%$ accordingly.

Table 9.: Variance Decomposition of GDP

\begin{tabular}{|c|c|c|c|c|c|c|}
\hline \multicolumn{7}{|c|}{ Variance Decomposition of GDP } \\
\hline Period & S.E. & OPV & TB & PRS & PS & GDP \\
\hline 1 & $0.15^{304.2}$ & $4.02355^{3}$ & 1.249362 & 4.179429 & 0.930888 & 89.61677 \\
\hline 2 & 0.162605 & a5. 74,6131 & $2.88564,0$ & $6.1734,88$ & 1.882644 & 83.31210 \\
\hline 3 & 0.168680 & 5.681864 & 2.682725 & 7.655217 & 5.608871 & $7^{8.3} 7_{132}$ \\
\hline 4 & 0.169903 & $6.7655^{38}$ & 2.74 .6981 & $7 \cdot 5^{8} 5831$ & 5.628327 & $77 \cdot 27332$ \\
\hline 5 & 0.171736 & $7 \cdot 529868$ & 2.910607 & 7.927013 & 5.567321 & $7^{6.06} 519$ \\
\hline 6 & 0.171980 & $7 \cdot 5 \circ 8517$ & 2.903029 & $7 \cdot 98154^{3}$ & $5 \cdot 755^{228}$ & $75.85^{168}$ \\
\hline 7 & 0.172199 & $7.64,2630$ & 2.940686 & 7.961434 & $5 \cdot 742077$ & $75 \cdot 7^{1317}$ \\
\hline 8 & 0.172299 & $7.6565^{86}$ & 2.940312 & $7 \cdot 99194.1$ & $5 \cdot 7^{3} 5415$ & 75.67575 \\
\hline 9 & 0.172324 & 7.6604 .85 & $2.9397^{3} 7$ & $8.0065^{80}$ & $5 \cdot 7^{3} 7^{8} 4^{3}$ & $75.655^{36}$ \\
\hline 10 & $0.17234,0$ & 7.672687 & 2.940867 & 8.005676 & $5 \cdot 738659$ & $75 \cdot 64211$ \\
\hline
\end{tabular}

Source: Autors` 


\section{CONCLUSION}

The results and outcomes based on the time series data of oil price volatility, trade balance, private sector investment, public sector investment and gross domestic production of Pakistan from 1973 to 2014 .

Correlation coefficient test is used to measure the linear relationship between the variables. Gross Domestic Production has strong positive relation with Private Sector Investment, Public Sector Investment and Trade Balance and negative weak relation exist with Oil Price Volatility. Oil Price Volatility has moderate negative relation with Private Sector Investment and Public Sector Investment, weak negative relationship exist with Trade Balance.

Private Sector Investment has strong positive relation with Public Sector Investment and moderate positive relationship with Trade Balance. Public Sector Investment has moderate positive relationship with Trade Balance.

The linear regression model is used to find out the effect of oil price volatility and the other macro economic variables on the GDP. Public sector investment and Trade Balance has significant effect on Gross domestic production at $1 \%$ and $5 \%$ level of significance accordingly. Meanwhile, the oil price volatility and private sector investment have insignificant effect on the Gross domestic production. The Linear Regression Model describe that these independent variable define $87 \%$ about the dependent variable. The remaining portion of GDP of Pakistan is impact through other macro-economic variables which is only $13 \%$.

Afterward, Johenson co integration test is used to find out the short run and long run relation among the variables (oil price volatility, trade balance, private sector investment, public sector investment and gross domestic production). It is observed that 5 co integration equations are found at $5 \%$ level of significance. So it is concluded that oil price volatility, trade balance, private sector investment, public sector investment and gross domestic production have a long run relationship.

After implementing the vector autoregression (VAR), we utilized impulse response function to define the effect of different shocks. Impulse Response Function described that oil price volatility (OPV) sock effect itself, gross domestic production (GDP), private sector investment (PRS), public sector investment (PS) and trade balance (TB) and stabilized after 7 year, 5 year, 5 year, 8 year and 7 year respectively. Furthermore, gross domestic production (GDP) shock effect oil price volatility (OPV), itself, private sector investment (PRS), public sector investment (PS) and trade balance (TB) and stabilized after 8 year, 9 year, 9 year, 7 year and 8 year accordingly. Moreover, private sector investment (PRS) shock effect oil price volatility (OPV), gross domestic production (GDP), itself, public sector investment (PS) and trade balance (TB) and stabilized after 9 year, 8 year, 8 year, 9 year and 8 year correspondingly. In addition, public sector investment (PS) shock effect oil price volatility (OPV), gross domestic production (GDP), private sector investment (PRS), itself and 
trade balance (TB) and stabilized after 8 year, 8 year, 6 year, 7 year and 5 year respectively. At last, trade balance (TB) shock effect oil price volatility (OPV), gross domestic production (GDP), private sector investment (PRS), public sector investment (PS) and itself and stabilized after 9 year, 8 year, 7 year, 7 year and 5 year accordingly. Variance decomposition described that variation of oil price volatility, trade balance, private sector investment, public sector investment and gross domestic production is $100 \%, 97.39 \%, 76.4 .8 \%, 92.35 \%$, and $89.62 \%$ accordingly due to itself at first year but it is decreasing after time to time and reached at $90.33 \%, 87.85 \%$, $37.14 \%, 59.20 \%$ and $75.64 \%$ respectively. 


\section{REFERENCE}

Ahmed, F., The effect of oil prices on unemployment: evidence from Pakistan. Business and economics journal, 4(1), (2013): 43-57

Akpan, E., Oil price shocks and Nigeria's macro economy. Journal of Economics, 4.(2), (2009): 12-19

Aliyu, S., Impact of Oil Price Shock and Exchange Rate Volatility on Economic Growth in Nigeria: An Empirical Investigation. Journal of international studies, 11(1), (2009): 4- ${ }^{-15}$

Aliyu, S.R.U., Impact of Oil Price Shock and Exchange Rate Volatility on Economic Growth in Nigeria: An Empirical Investigation. Research Journal of International Studies, 11(1), (2011)

Anderton, R. and Skudelny F., Exchange Rate Volatility and Euro Area Imports. (2001), European Central Bank (ECB), Working Paper, No. 64.

Awerbuch, S., \& Sauter, R., Oil price volatility and economic activity: a survey and literature review. (2003), IEA Research Paper.

Cerralo, J., Do oil price shocks matter? Evidence from some European countries. Energy Economics, 25(2), (2005): $137^{-154}$

Chen S, Hsu K., Reverse Globalization: Does High Oil Price Volatility Discourage International Trade? (2012), Munich Personal RePEc Archive, MPRA Paper No. 36182.

Darby, M.R., The price of Oil and World Inflation and Recessions. American Economic Review, 72(4), (1982): $738-75^{1}$

Dissou, Y., Oil price shocks: Sectoral and dynamic adjustments in a small-open developed and Oilexporting economy. Energy policy, 38(1), (2010): 562-572

Dornbusch, R., Fisher, S. and Startz, R., Macroeconomics, McGraw-Hill, Ltd. 2001.

Edelstein, P. and Kilian, L., How Sensitive Are Consumer Expenditures to Retail Energy Prices? Journal of Monetary Economics, 56(1), (2009): 766-779

Eksi, I.H., Senturk, M., and Yoldirm, H.S., Sensitivity of stock market indices to Oil prices: Evidence from manufacturing sub-sectors in Turkey. Panoeconomicus, 4,(1), (2012): 4,63-474

Eryigit, M., Effects of oil price changes on the sector indices of Istanbul stock exchange. International Research Journal of Finance and Economics, 25(2), (2009): 209-216

Hamilton, J.D., What is an Oil Shock?. Journal of Econometrics, 113(1), (2003): 363-398

Jacobs, J., Kuper, G.H. and van Soest, D.P., On the effect of high energy prices on investment. Applied Economics, 41(27), (2009): 3483-3490

Jamali, B., Shah, M.A., Soomro, J., Hassan, Shafiq. and Shaikh, M.F., Oil price Shocks: A Comparative study on the Impacts in Purchasing Power in Pakistan. Modern applied Sciences, 5(2), (2011): 192-203

Jawad, M., Oil Price Volatility and its Impact on Economic Growth of Pakistan. Journal of Finance and Economics, 1(4), (2013): 62-68

Katircioglu, S. T., Sertoglu, K., Candemir, M. and Mercan, M., Oil Price Movements and Macroeconomic Performance: Evidence from Twenty-Six oecd Countries. Renewable and Sustainable Energy Re-views, 44, (2015): $257^{-270}$

Kiani, A., Impact of High Oil Prices on Pakistan's Economic Growth. International Journal of Business and Social Sciences, 2(17), (2011): 209-216 
Olomola, P., Oil price shocks and aggregate economic activity in Nigeria. African Economic and Business Review, 4.(2), (2006): 40-45

Pirog, R., Natural gas prices and market fundamentals. CRS Report for Congress Congressional Research service. 2004.

Rafiq, S., Salim, R., and Bloch, H., Impact of crude oil price volatility on economic activities: An empirical investigation in the Thai economy. Resources Policy, 34,(1), (2008): 121-132

Rebeca, R.J., and Sanchez, M., Oil price shocks and real GDP growth: Empirical evidence for some OECD countries. (2004), European Central Bank, Working Paper No 362.

Rebeca, R.J., and Sanchez, M., Oil shocks and the macro-economy: A comparison across high Oil price periods. Applied Economics Letters, 16 (16), (2009): 1633-1638

Ricardo, H. and Roberto, R., An Alternative Interpretation of the Resource Curse: Theory and Policy Implications. (2003), NBER Working Paper No. 9424.

Salim, R. and Rafiq, S., The Impact Of Crude Oil Price Volatility On Selected Asian Emerging Economies, (2013): 1-33. (http://www.wbiconpro.com/220-Salim.pdf.)

Sandrine, L. and Mignon, V., Oil prices and economic activity: An asymmetric cointegration approach. Energy Economics, 3०(3), (2008): $847^{-8} 85$

Sardorsky, P., Oil Price Shocks and stock market activity. Energy Economics, 21 (5), (1999): 449-469

Siddiqui, M. M., Oil Price fluctuation and Stock Market Performance The case of Pakistan. Journal of International business and economics, 2(1), (2014): 47-53

Stevens, P., Oil markets. Oxford Review of Economic Policy, 21 (1), (2005): 19-42

Zaman, U., Faroog, M. and Ullah, S., Sectoral oil Consumption and economic growth in Pakistan and ECM approach. American journal of scientific and industrial research, 2(2), (2011):149-156 